\section{Iguana delicatissima (Lesser Antillean Iguana). Conservation.}

Date of observation: 9 May 2010. Location: Guadeloupe, Îles de La Petite Terre, Île de Terre de Bas. Coordinates: 16.1716, -61.1205. Elevation: $3 \mathrm{~m}$. Voucher: image by C. Pavis. The nature reserve of Petite Terre hosts the highest population density (Lorvelec O, Pascal M., Pavis C \& Feldmann P, 2007, Applied Herpetology, 4, 131-161) of this endangered species (Breuil M, Day M \& Knapp C, 2010, Iguana delicatissima, in IUCN Red List of Threatened Species). We observed a mature iguana with a trifid tail perched in a tree (Pisonia sp.). Tail furcations in insular rock iguana populations (genus Cyclura) were only recorded in populations that coexist with introduced mammalian predators, especially Ship Rats (Rattus rattus), and appeared to be results of failed predation attempts (Hayes WK, Iverson JB, Knapp CR \& Carter RL, 2012, Biodivers Conserv, DOI 10.1007/s10531-012-0276-4). Our observation suggests that $R$. rattus might pose a potential threat to the iguana population of Petite Terre. A similar interaction probably occurred in Guadeloupe, where a 19th-century I. delicatissima with a trifid tail was reported by Brygoo (1990 '1989', Bull Mus Natl Hist Nat, sér 4 A, 11(3), 3-112, p 73). Accompanied by Julien Athanase, Nicolas Barré, Joël Berchel, Mathieu Brossaud, Laurent Malglaive, and Claudie Pavis.
Olivier Lorvelec, INRA, UMR985 Écologie et Santé des Écosystèmes, Campus de Beaulieu, Rennes, 35000, France, Olivier.Lorvelec@rennes.inra.fr.

Citation: Lorvelec 0. 2012. Iguana delicatissima (Lesser Antillean Iguana). Conservation. Caribbean Herpetology 29:1.

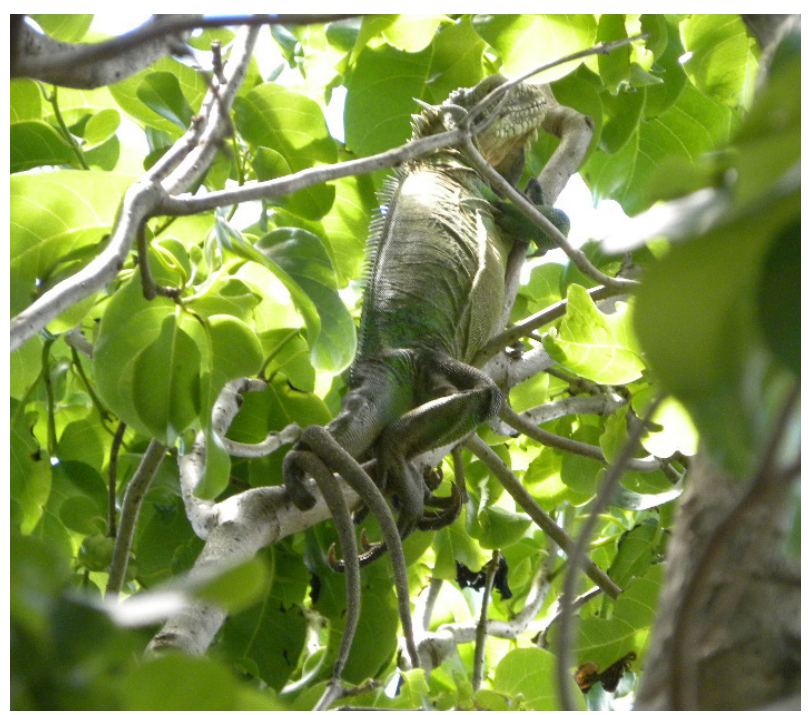

